\title{
INTERDISCIPLINARITY IN STUDYING MODERN RUSSIAN POETRY IN SCHOOL
}

\author{
Alina R. Gaynutdinova \\ Kazan Federal University, Kazan, Russia \\ Alfiya F. Galimullina \\ Kazan Federal University, Kazan, Russia \\ Artem E. Skvortsov \\ Kazan Federal University, Kazan, Russia \\ Sergey A. Zinin \\ Moscow Pedagogical State University, Moscow, Russia
}

E-mail: alfiya_gali1000@mail.ru

Recepción: 05/08/2019 Aceptación: 18/09/2019 Publicación: 23/10/2019

\section{Gitación sugerida:}

Gaynutdinova, A.R., Galimullina, A.F., Skvortsov, A.E. y Zinin, S.A. (2019). Interdisciplinarity in studying modern russian poetry in school. 3C TIC. Cuadernos de desarrollo aplicados a las TIC. Edición Especial, Octubre 2019, 274-285. doi: https://doi. org/10.17993/3ctic.2019.83-2.274-285

\section{Suggested citation:}

Gaynutdinova, A.R., Galimullina, A.F., Skvortsov, A.E. \& Zinin, S.A. (2019). Interdisciplinarity in studying modern russian poetry in school. 3C TIC. Cuadernos de desarrollo aplicados a las TIC. Special Issue, October 2019, 274-285. doi: https://doi. org/10.17993/3ctic.2019.83-2.274-285 


\section{ABSTRACT}

In the methodology of teaching literature and in school practice, traditionally much attention is paid to the problem of interdisciplinary connections, while the issues of intra-disciplinary interaction of literary material within the school course are not sufficiently developed by methodologists. The presence of this problem is felt especially acute in the study of literature in high school, when students " knowledge is generalized not only at the synchronic, but also diachronic levels. With consistent updating of various levels of artistic communication, the study of the historical and literary course acquires a broad dialogical focus, forming the skills of contextual examination of literary phenomena in students.

In this article, we will consider building intra-disciplinary relations in the lessons of studying modern Russian poetry at school. First, various artistic universals (archetypes, mythologems, topos, "eternal" motives) are actualized, which have important methodological significance and allow students to make broad historical and cultural generalizations at the lessons. Holistic comprehension of a work of art in the context of the historical and literary process is determined by the definition of various types of intertext artistic interactions (borrowings, imitations, parodies, reminiscences, citations) reflecting the principle of continuity of literary phenomena. At the same time, it is very important to identify historical and biographical ties, a creative dialogue between contemporary poets and poets of various eras. It can be mentoring, apprenticeship, co-authorship, rivalry, continuity, tradition actualization, "attraction - repulsion" type of relationships, influence, and others.

\section{KEYWORDS}

Methods of Teaching Literature, Intra-Disciplinary Relations, Innovative Methods of Teaching Literature, Modern Russian Poetry. 


\section{INTRODUCTION}

Intra-disciplinary relations links in literature lessons can be actualized primarily through students' perceptions of the successive connections of modern poetry with previous literature. The theoretical understanding of the issue of traditions in scientific literature is presented in various aspects: historical-philosophical, social-philosophical, cultural, axiological, historical-literary and methodological. Tradition is a multi-level category, requiring the study of artistic and aesthetic categories in their historical development, due, above all, to the specifics of the worldview of both the transmitting and the receiving parties.

The question of tradition is one of the urgent problems of modern cultural studies. In the works of foreign and Russian researchers: philosophers, ethnographers, cultural scientists, literary scholars and methodologists (K. Lévi-Strauss, V. Terner, S. S. Averintsev, E. A. Baller, Yu. B. Borev, A. S. Bushmin, A. Ya. Zis, O. A. Krivtsun, Yu. M. Lotman, A. F. Losev, E. Shatsky) the problems of the origin of tradition, its morphological structure and functional originality are considered (Lévi-Strauss, 2000; Shatsky, 1990).

The analysis of works devoted to the study of the problem of traditions allows us to identify the types of functioning of traditions. In the structural form, they can be represented as follows: background, quote, stylization, parody.

In this article, on the example of a lesson devoted to the actualization of intrasubject relations in the study of modern poetry, we turn to the lesson-analytical conversation in conjunction with the project's method, as well as the research students' activities. At the lesson, high school students develop skills of working with various information (reading and retelling of poetic text, complex, comparative and benchmarking analysis of works of art, working with literary-critical, cultural and historical sources, with scientific and popular literary texts, search skills and critical understanding of information taken from Internet sources). 
Consideration of modern Russian poetry in literature classes in high school in terms of the manifestation of traditions and innovation allows you to successfully prepare for the final exams. In preparation for thelesson "Traditions and Innovation in Modern Russian Poetry", the teacher invites students to independently choose one topic for independent research and development activities, the results of which will be presented in the lesson in the form of public defense of an individual or collective project (2-3 students in a group) accompanied with a multimedia presentation. Pupils are offered the following topics:

1. Are there copyrights of the traditional plot about the return of the prodigal son found in contemporary Russian poetry? What changes is undergoing this traditional plot scheme in specific works?

2. Continue the series of Russian poets with 2 - 3 names of modern poets who in their work presented the archetypical composition of the cosmos chaos: A. S. Pushkin, M. Yu. Lermontov, F. I. Tyutchev, A. A. Blok, S. A. Esenin, V. V. Mayakovsky.

3. Give 2 - 3 examples of poems from the works of modern Russian poets, which represent the image of the House, the hearth shelterin its archetypal sound.

5. Images of the moon and sun in the poetry of Russian classics and modern poets (M. V. Lomonosov, G. R. Derzhavin, A. S. Pushkin, M. Yu. Lermontov, F. I. Tyutchev, A. A. Fet, K. D. Balmont, A. A. Akhmatova, M. I. Tsvetaeva).

6. The theme of poetry and monument in Russian classical and modern poetry. Argue your answer with examples from $2-3$ works of art.

7. The game as an artistic device in classical and modern Russian poetry.

8. The role of parody in modern Russian poetry. 
This topic allows pupils to join the modern Russian poetry, to get acquainted with the life and work of modern poets of different directions (E. E Evtushenko, A. Voznesensky, B. Akhmadullina, J. Moritz, I. Lisnyanskaya, I. Mashinskaya, O. Chukhontsev, M. Amelin, A. Kouchner, E. Rein, I. Brodsky, S. Gandlevsky, etc.).

\section{METHODOLOGY}

The study of philosophical, cultural and literary works, revealing the scientific content of the terms "literary tradition", "continuity", "literary interrelations", "intertext" and others, allowed us to determine the theoretical content of the methodical system of forming ideas about literary traditions among senior pupils of secondary schools and gymnasiums.

The problem of interdisciplinary interrelations of the school literature course is thoroughly developed in the works of well-known scientists and methodologists S. A. Leonov, V. G. Marantzman, I. A. Podrugina, E. S. Rogover, V. F. Chertova, R. F. Mukhametshina, A. F. Galimullina, as well as in the publications of contemporary researchers: R. R. Zamaletdinova, G. A. Golikova, A. H. Vafina, various forms of lessons and methods for identifying intra-disciplinary relations are presented in the works of the Russian classics Literature teaching methods: G. I. Belenky, T. G. Brazhe, O. Yu. Bogdanova, V. A. Domansky (Podrugina, 2000; Zamaletdinov et al., 2016).

Zinin (2004) in the monograph "Intra-disciplinary connections in the study of the school's historical and literary course" offers a theoretically sound and proven in the practice of introducing the school curriculum for literature and textbooks the original system of using intra-disciplinary connections, both "horizontal" and "vertical » in high school, as well as identifying their role in shaping of the senior pupils reading culture. In our study, we rely on the methodology proposed by S. A. Zinin. 
In the publications of A. S. Afanasyev, T. N. Breeva, V. N. Krylova, N. G. Makhinina, N. G. Komar, the experience of studying modern Russian literature is presented in the context of successive links with the preceding Russian literature, as well as in the context of main trends of the global literary process (Afanasev et al., 2017; Afanasev \& Breeva, 2016; Krylov, 2017; Makhinina et al., 2017; Galitsky, 2016; Korsunsky, 1985).

All the mentioned studies became the methodological basis for our research and allowed us to develop a generalizing lesson using innovative technologies. The basis of the study were historical-genetic, historical-functional, comparative and typological approaches to the examination of modern Russian poetry, to reveal traditions, successive links with previous literature and innovation.

\section{RESULTS AND DISCUSSION}

This form of the lesson requires each pupil to thoroughly prepare independently after school hours. Pupils independently choose a topic for the project, select a material, conduct a comparative and comprehensive analysis of the works of modern Russian poets of choice, prepare a multimedia presentation at the final stage of the project, and during the lesson they defend their research work accompanied by a multimedia presentation. The project can be executed both individually and as a group of $3-4$ pupils.

Let's stop on some fragments of this lesson in more detail. Exploring the traditional for world, including Russian poetry, the theme of poetry and a monument in Russian classical and modern poetry, pupils choose creativity of poets who most clearly reflected this topic in their creativity. Pupils independently formulate this theme as "The theme of the poet and poetry in Russian literature" or "The theme of the immortality of poetry in Russian literature." Anticipating performances with projects, the teacher offers to think about what is a monument; what can be a monument to the poet, can the works of the poet become a monument to him? 
Pupils respond that the monument is a sculptural structure in memory of an outstanding writer, commander, statesman. The monuments are named to Peter I, M. V. Lomonosov, N. V. Gogol, G. Tukai, M. Jalil, P. I. Tchaikovsky. The pupils note that the best monument to the poet, writer, artist, musician is his own outstanding works, which are interesting for subsequent generations with their aesthetic value, humanistic aspiration, originality of thought and feeling, and harmonious sound. Poetry of M.V. Lomonosov, G.R. Derzhavin, A. S. Pushkin, M. Yu. Lermontov, F. I. Tyutchev survived their time. Next, pupils defend their project dedicated to this topic. They carry out a comparative analysis of the ode of Horace "To Melpomene", of its first translation into Russian by M. V. Lomonosov "My works defined the badge of immortality of mine ...", the original poems of G. R. Derzhavin "Monument", A. S. Pushkin "It's not a manmade monument that I've created for myself", "Monuments" by V. Bryusov and I. Brodsky and other modern poets who wrote various variations on the theme of a poetic monument. Pupils conclude that every poet, keeping the form of the original source, contributes to the development of this topic.

The special interest of pupils is attracted by the themes: "Game as an artistic technique in classical and modern Russian poetry" and "The Role of Parody in Modern Russian Poetry", which is closely related to the literature of postmodernism. Working on this topic, students turn to the creative works of I. Brodsky, T. Kibirov, S. Gandlevsky, O. Chukhontsev, D. Samoilov, Y. Levitansky, I. Irtenyev, Tsvetkov, A. Kushner, etc. During the lesson, students come to the well-founded conclusion that the game of the so-called "archaists" is an artistic device, among the "innovators" as the goal of poetry, and among the "centrists" as an expression of world perception.

\section{SUMMARY}

During reflection, students note that reading modern Russian poetry revealed a variety of authors' creativity, gave rise to a desire to learn more about their life path, even to communicate with them (pupils have such an opportunity, because 
many poets run personal websites and are very active on social networks). The lesson devoted to contemporary Russian poetry in the context of traditions convinced pupils that literature is a living and actively developing phenomenon of the modern cultural life of Russia.

One of the most important tasks of education of the qualified reader at school is development at pupils of ability to deep comprehension of the literary work as the complete art phenomenon. In the artistic impression a large role belongs personally significant to the reader. As E. O. Galitsky notes: “... there is an integrating beginning of the development of a person's thinking, his spiritual practices is meaningful reading" (Galitsky, 2016, p.7). Consequently, if the personal meaning of works of art is consonant with the personal sense of the perceiver or acquires such a meaning, then certain personal attitudes are developed, which are then realized out of art, in ordinary life situations. Then the thoughts and feelings of the writer are perceived by readers as their personal, innermost thoughts and feelings.

\section{CONCLUSIONS}

The structure of reading abilities is well developed by modern psychology and literature teaching methods (Korsunsky, 1985). The components of this structure are: reader's susceptibility, observation, reader's emotions, feelings, reader's empathy (ability to empathize), thinking with verbal and artistic images; reader's imagination, verbal-shaped memory. The development of these abilities is promoted: reading orientation, reading attitudes, needs, reading motives, the ability to relate what is read to life experience (Korsunsky, 1985, p.4 - 38) Consequently, the study of literature should be creative work, intense, responsible and exciting. 
Identification of various types of dialogical relations within Russian poetry from the depth of centuries to the present day allows us to significantly enrich the lessons of literature, form communication, reading and research competences of students, which allows pupils to maintain a high cognitive interest in the mastering Russian literature as a subject.

\section{ACKNOWLEDGMENTS}

The work is performed according to the Russian Government Program of Competitive Growth of Kazan Federal University.

\section{REFERENCES}

Afanasev, A., \& Breeva, T. (2016). Gender picture of peace in Russian women rock-poetry (poetic novels "Sprinter" and "StaLker" by Diana Arbenina). Fournal of Language and Literature, 7(1), 159-162. Retrieved from http://dspace.kpfu.ru/xmlui/bitstream/handle/ net/145386/SGOPUS20 780303-2016-7-1-SID84998631659-a1. pdf;jsessionid=DCEBA61528BA2A3467B89851CADB7EC6? sequence=- 1

Afanasev, A., Breeva, T., \& Domansky, J. (2017). Poetic system interaction by Yanka Dyagileva and Egor Letov. Astra Salvensis, 5(10), 367-374. Retrieved from http://dspace.kpfu.ru/xmlui/bitstream/handle/net/130601/ SCOPUS23934727-2017-5-10-SID85038888217-a1.pdf? sequence=-1

Ghertov, V. F. (2012). School study of Russian literary classics in comparative historical coverage / V.F. Chertov. Study of Russian literary classics at school: yesterday, today, tomorrow: XIX Golubkovsky readings: digest of articles. MSPU, 5 - 11 .

Galitsky, E. O. (2016). Reading With Passion: Life-Creative Workshops. Bibliomir.

Korsunsky, E. A. (1985). Development of Literary Abilities of Pupils. Prosveshenie. 
Krylov, V. I. (2017). Ideas about national identity in russian literary review, historical and literary discourses of the 19th-early 20th century. $C B U$ international conference proceedings 2017: Innovations in Science and Education, 5, 680685. doi: https://doi.org/10.12955/cbup.v5.1007

Lévi-Strauss, G. (2000). The Mythologiques (vol.1, 2, 3, 4).

Shchepacheva, I., Komar, N., Makhinina, N., Sidorova, M., \& Berdnikova, O. (2017). Contemporary Christian Tale for Children: Questions of Poetics and Problems. Fournal of History Culture and Art Research, 6(4), 647-654. doi: http://dx.doi.org/10.7596/taksad.v6i4.1158

Podrugina, I. A. (2000). Typology of School Analysis of Epic Works in High School. Latmes.

Shatsky, E. (1990). Utopia and Tradition: Translation from Polish. Progress.

Zamaletdinov, R. R., Vafina, A. H., Mukhametshina, R. F., \& Golikova, G. A. (2016). The "New" Strategy in Teaching Literature in a Multiethnic Environment (as Exemplified by the Republic of Tatarstan). International Fournal of Environmental and Science Education, 11(6), 1237-1246. Retrieved from https://files.eric.ed.gov/fulltext/EJ1114295.pdf 
Edición Especial Special Issue Octubre 2019 DOI: https://doi.org/10.17993/3ctic.2019.83-2.274-285 